\title{
Experiences of Middle-Level Students, Teachers, and Parents in the Do the Write Thing Violence Prevention Program
}

\author{
Sarah E. Peterson \\ University of Texas at El Paso \\ R. Craig Williams \\ University of Texas at El Paso \\ Rick A. Myer \\ University of Texas at El Paso \\ Josefina V. Tinajero \\ University of Texas at El Paso
}

\begin{abstract}
We examined experiences of participants in Do the Write Thing national violence prevention program for middle-level students. Using mixed methods, we conducted surveys and focus groups with students, parents, and teachers who attended the program's National Recognition Week in Washington, DC. Results revealed important affective, behavioral, and cognitive impacts on participants, including improved relationships, increased understanding of violence, and commitment to reduce violence. Participants from cities where insufficient time and resources were devoted to the project did not experience significant change. Teachers reported developing greater empathy for their students and making substantial changes in their teaching, providing support for students and infusing activities addressing violence into their curriculum. Recommendations are made for increased program support and future research.
\end{abstract}

Keywords: violence, middle school, intervention, writing

\section{Introduction}

Thousands of children in the United States suffer at home and school due to experiences with violence. According to the National Survey of Children's Exposure to Violence, more than $60 \%$ of children had either directly experienced or were exposed to violence in the previous year including assault, robbery, vandalism, theft, physical/emotional/sexual abuse, neglect, abduction, or witnessing a violent act. More than one third had experienced multiple victimizations, with $10 \%$ experiencing as many as five or more victimizations in 1 year (Finkelhor, Turner, Ormrod, Hamby, \& Kracke, 2009). In addition, it is estimated that $10-33 \%$ of school-age students have reported being victimized by bullying, and 5-13\% have bullied others (Hymel \& Swearer, 2015).

The affective, behavioral, and cognitive impacts of these types of violence taking place in communities, families, and schools have been researched extensively (e.g., Armsworth \& Holaday, 1993; Holt, Buckley, \& Whelan, 2008; Margolin \& Gordis, 2000; Zona \& Milan, 2011). Short-term effects of violence include depression and anxiety, aggressive behavior, disruptions in relationships with caregivers, posttraumatic stress disorder symptoms, difficulties in establishing peer networks, 
cognitive and academic difficulties, ineffective work habits at school, school failure, and sometimes long-term consequences such as partner abuse and increased risk of criminal behavior (Fowler, Tompsett, Braciszewski, Jacques-Tiura, \& Baltes, 2009; Margolin \& Gordis, 2000, 2004). In addition, youth who have been victimized, when compared with nonvictimized peers, are 2.5 times more likely to report suicidal ideations, more than 3 times as likely to report suicidal behaviors, twice as likely to end up unemployed, and two thirds more likely to be on welfare (McWhirter, McWhirter, McWhirter, $\&$ McWhirter, 2013). Although being personally victimized by community violence was found to impact young people the most, simply witnessing or hearing about violence was also significantly related to symptoms of posttraumatic stress disorder, anxiety, and depression (Fowler et al., 2009).

Numerous studies have also examined bullying in schools. According to the National Education Association (2012), approximately 160,000 children per day miss school due to fear of being bullied. Bullying includes behaviors such as spreading rumors, rejecting or ostracizing others, excluding others from activities, and using nasty names; it may or may not involve aggression or violence (Ttofi \& Farrington, 2011). Research on bullying shows that it can lead to similar problems as other types of violence and in more extreme cases, suicide, and homicide (Beck, 2013). McDougall and Vaillancourt (2015) concluded that during childhood and adolescence, peer victimization can impact the academic functioning, physical health, social relationships, self-esteem, and mental health of those bullied. Consequently, research on bullying suggests that impacts of peer victimization are very similar to those from experiences with community and family violence. However, sometimes no differences are observed between victims and nonvictims of bullying, indicating that not all children experience long-term negative impacts. Individuals who have been bullied at younger ages can recover from victimization if the bullying stops (McDougall \& Vaillancourt, 2015). Negative impacts are less likely when children have a best friend, family support, and strong emotional support from teachers, especially when families do not provide support. In addition, a systematic review of research on protective factors against long-term effects of bullying concluded that high academic achievement and good social skills are associated with resilience against both bullying perpetration and victimization (Ttofi, Bowes, Farrington, \& Losel, 2014).

In an attempt to curb bullying, many school districts have implemented bullying prevention programs. A systematic review and meta-analysis of research on these programs indicates that they are moderately effective, with a $20-23 \%$ decrease in bullying and a $17-20 \%$ decrease in victimization (Ttofi \& Farrington, 2011). Effective program elements for decreasing victimization include duration and intensity of the program for children and teachers, parent training/meetings, firm discipline methods, and videos and cooperative group work. Additionally, Eliot, Cornell, Gregory, and Fan (2010) found that students are more likely to be favorable toward seeking help for bullying and threats of violence when they perceive teachers and staff to be supportive. In contrast to these effective program elements, working with peers to tackle bullying, specifically peer tutoring, peer mediation, and encouraging bystander intervention, were associated with an increase in victimization and, therefore, are not recommended (Ttofi \& Farrington, 2011).

Other school-based programs have been implemented to reduce or prevent other types of violence. Some of these programs focus on specific types of violence, such as dating violence (Jaycox et al., 2006; La Rue, Polanin, Espelage, \& Pigott, 2016) and media violence (Fingar \& Jolls, 2014). In contrast, some programs address all types of violence but take varying approaches to reducing violence, including, for example, conflict resolution (Shuval et al., 2010), social development curriculum (Jagers, Morgan-Lopez, Flay, \& Aban Aya Investigators, 2009), theater-based programs (Zucker et al., 2010), and universal school-based programs (e.g., Crooks, Scott, Ellis, \& Wolfe, 2011; Farrell, Mehari, Kramer-Kuhn, Mays, \& Sullivan, 2015). 
One such school-based program is Do the Write Thing (DtWT), a national violence prevention program for middle-level students (http://www.dtwt.org). It was conceived and initiated as an opportunity for community, business and government leaders to make resources available to help students make a lasting commitment to take personal responsibility for ending violence in their lives, homes and communities. The program has been supported extensively by juvenile justice professionals for its 20 years of existence with an estimated 1,800,000 students participating. However, little research has been conducted to examine specifically how it impacts the participants and their schools, families, and communities. Therefore, this study was designed to examine the impact of this large-scale national program for middle-level students.

\section{Do the Write Thing Challenge Program}

As the major initiative of the National Campaign to Stop Violence, DtWT targets students' experiences with all types of violence, including but not limited to bullying. Participating middle schools from around the country challenge their students to make a commitment to work toward preventing violence in their schools and communities. The major program component common to all participating schools is having students write about violence. They may use various forms of written expression (e.g., essays or poems) as long as they are the work of each individual student.

Specifically, students are asked to address (a) how violence has affected their lives, (b) what they see as the causes for this violence, and (c) ways they might help prevent future violence.

Aside from student writings, the program does not prescribe a common curriculum or set of learning activities. However, the "Challenge" has been aligned with the Common Core English Language Arts Standards in Writing for Grades 7 and 8, and it is strongly recommended that teachers use learning activities that allow them to engage students in rich discussions about the impact of violence. Activities might include having guest speakers, discussing scenarios focused on violence, or watching videos. Teachers are free to use any of these various classroom activities, giving them flexibility to incorporate the program into their school's curriculum and align with state standards.

Each year, schools submit their highest quality student writings to a local Blue Ribbon Panel that typically includes community leaders such as judges, lawyers, university professors, and

business/government professionals who are committed to reducing youth violence in their city. Blue Ribbon Panel members score the writing submissions received from the schools to identify a group of semi-finalists, who are then interviewed. The Blue Ribbon Panel selects a top male and female to serve as the city's ambassadors. Each summer, the two ambassadors along with their DtWT teacher and one parent attend National Recognition Week in Washington, DC. Among other events, they meet with government leaders such as the secretary of education, the attorney general of the United States, Supreme Court justices, and/or their congressional representatives to share their views on youth violence. In addition, they visit the Library of Congress where their published writings are housed.

DtWT highlights five program elements. First, writing about violence students have experienced provides a therapeutic opportunity to address their personal experiences. Second, students are asked to accept personal responsibility for saying no to violence. Third, participating in the challenge creates an open line of communication between students and teachers: Students get a chance to write about their experiences and schools are provided with information not otherwise readily available. Fourth, opening up lines of communication between teachers and students helps them build a special bond. Finally, students are given the opportunity to share their ideas and solutions with community members and policy makers (e.g., elected officials, family court judges, business leaders), hopefully serving as a catalyst to get the community involved in antiviolence efforts. 
To the best of our knowledge, DtWT is unique in its focus on providing opportunities for middle-level students in a school setting to write in their own words about all types of violence they experience, not just limited to bullying. Research on writing interventions has focused mostly on therapeutic or medical settings but little research reports on potential benefits of school programs that use writing. In one school-based study of seventh grade students in Italy, results indicated that an expressive writing intervention focusing on peer problems improved students' coping strategies but not their internalizing problems (Giannotta, Settanni, Kliewer, \& Ciairano, 2009). A follow-up study also found that seventh graders living in violent urban neighborhoods who wrote about experiencing or witnessing violence reduced their aggression levels more than those who wrote about nonemotional topics (Kliewer et al., 2011). DtWT differs from these school-based writing intervention programs in that students submit only one essay; however, results of these studies show promise for the beneficial effects of giving students opportunities to write about the violence they experience or witness.

The current study addresses four research questions: (a) What factors influenced students' motivation for writing about violence that is the signature component of this program? (b) How did participation in the program impact participants? (c) What were participants doing to reduce violence? (d) What were participants' recommendations for supporting continued efforts to reduce violence?

\section{Method}

\section{Participants}

Participants included 49 students (24 females, 25 males) from 25 cities who attended DtWT's National Recognition Week in Washington, DC, in June 2014. Thirty-one had just completed eighth grade, 13 had completed seventh grade, and three had completed sixth grade, and their mean age was 13.5. They were selected as ambassadors from their home city based on evaluations of their essays and interviews with their Blue Ribbon Panel of judges in each city. Each student ambassador was accompanied by one parent, their DtWT teacher, and the city's DtWT coordinator. They were recruited to participate in the research project during regularly scheduled sessions of activities for National Recognition Week, using standard Institutional Review Board protocol for adult consent, parent permission, and child assent. Participants who consented to participate in the study included all 49 student ambassadors, 41 parents (19 female, 21 male, one unspecified) and 38 teachers (26 female, nine male, one unspecified).

\section{Research Design and Measures}

A mixed methods design allowed for systematic and efficient examination of participants' experiences while also adding richness provided by qualitative data to enhance survey data. Questionnaires were developed to address three general areas of interest: (a) factors influencing students' motivation for writing DtWT essays, (b) impact of participation in DtWT, and (c) commitment to reduce violence. Parallel Likert items were constructed for each group of participants (i.e., students, parents, and teachers), who responded on a 6-point scale ranging from 1 (strongly disagree) to 6 (strongly agree). Five items addressed the first research question regarding motivational factors for writing essays: (a) being selected as a program ambassador to attend National Recognition Week, (b) self-efficacy for writing, (c) trying one's best, (d) getting good grades and/or extra credit, and (e) having classroom discussions about violence. To address the second research question regarding impact of participation, we created three subscales. Subscale 1 (six items) assessed impact of the program on relationships (e.g., "I try harder to resolve problems with 
my friends since participating in DtWT'); Cronbach's alphas for the three participant groups ranged from .69 to .84. Subscale 2 (six items) assessed empathy for victims of violence (e.g., "I have more compassion for victims of violence since participating in DtWT"); Cronbach's alphas ranged from .60 to .62. Subscale 3 (three items) assessed participants' commitment to address violence (e.g., "I am committed to participate in a follow up project to improve my school and/or community"); Cronbach's alphas ranged from .61 to .62 .

Focus group questions were designed to add depth to our understanding of how the program impacted participants. Parallel questions were developed for each group of participants and addressed the following: (a) personal impact of participation in DtWT, (b) changes in schools and homes as a result of participation in DtWT, (c) actions taken to reduce violence since participation in DtWT, and (d) recommendations for continuing efforts to reduce violence.

\section{Data Collection Procedures}

Organizers of National Recognition Week scheduled two meetings with each of the three groups (students, teachers, parents) at predetermined times. At the first meeting with all groups present, researchers explained the research activities and obtained IRB approved adult consent, parent permission, and student assent to participate. Surveys were then distributed and collected. During the second scheduled meeting with each group of participants, coauthors conducted focus group interviews in breakout sessions, each with groups of six to 10 participants. All focus groups were audio recorded.

\section{Data Analysis}

Survey data were entered into SPSS and one-way analyses of variance were used to compare responses of the three respondent groups. Graduate assistants transcribed recordings of the focus groups to prepare for data analysis. Analysis of responses involved a standard inductive approach, permitting themes and patterns to emerge, which were then coded and selected for reporting. Analyses proceeded in two stages, allowing for systematic empirical inquiry into meaning (Shank, 2002). The four authors each analyzed group sessions individually and then collectively utilizing transcripts and notes on the sessions. We first became familiar with participants' responses individually by adopting a "close reading," highlighting relevant thoughts and making margin notes. Second, we worked in pairs to develop themes reflecting the participants' responses to each question. Third, we came together as a team to discuss and refine the themes that emerged from each step of the process. This systematic analysis of transcripts provided clues and insights as to how the program activities were perceived by the participants. Through this multistep process, we came to a common understanding that participants' responses for the first three questions could be interpreted as falling into three broad categories of impact: affective, behavioral, and cognitive. Affective impacts were those that focused on feelings and emotions, with two subthemes including empathy (experiencing feelings with somebody based on an understanding of how they feel) and sympathy (experiencing feelings for somebody). Behavioral impacts focused on observable actions and included subthemes of empowerment (enabling one to act), support (taking care of others), and communication (engaging in dialogue). Cognitive impacts focused on thoughts and understanding, including subthemes of tolerance (acceptance of differences), efficacy (belief in one's ability to act and accomplish), helplessness (sense of not being able to act or make an impact), perspective (one's view of a situation), and complexity (multidimensional meaning or understanding). Sample quotes are provided to illuminate these themes and provide detail to the reporting. 


\section{Results}

Results of surveys are presented first, followed by results from focus groups regarding ways in which participants experienced affective, behavioral, and cognitive impacts from their participation. The types of actions participants have taken to reduce violence are then presented followed by participants' recommendations for continuing efforts to reduce violence.

\section{What Factors Influenced Students' Motivation for Writing Essays on Violence?}

Table 1 shows mean responses to survey items measuring motivation for writing essays. Students were most motivated by trying their best and having classroom discussions on violence, and parents believed that their children were most motivated by the same factors. Teachers did not respond to all of the same motivation items, but they believed that students were most motivated by self-efficacy for writing and participating in classroom discussions about violence. It is encouraging that the 49 student ambassadors attending National Recognition Week were not primarily motivated by the competition component of the program. This finding is particularly important because only two students from each participating city were selected. In fact, many ambassadors expressed total surprise that they were chosen. These results also suggest that meaningful classroom discussions can be beneficial in motivating students to write about their experiences and understandings of violence, and their commitment to reduce violence, which is important given the findings of Kliewer et al. (2011) that aggression levels decreased for students who wrote about experiencing or witnessing violence.

Table 1: Participants' Ratings of Student Motivational Factors for Writing Essays

\begin{tabular}{|c|c|c|c|c|c|}
\hline \multirow[b]{2}{*}{ Group } & \multicolumn{5}{|c|}{ Motivational Factors } \\
\hline & $\begin{array}{c}\text { Being } \\
\text { Selected as } \\
\text { Ambassador }\end{array}$ & $\begin{array}{c}\text { Always Try } \\
\text { Their Best }\end{array}$ & $\begin{array}{l}\text { Self-Efficacy } \\
\text { for Writing }\end{array}$ & $\begin{array}{l}\text { Good Grade } \\
\text { or Extra } \\
\text { Credit }\end{array}$ & $\begin{array}{c}\text { Classroom } \\
\text { Discussions } \\
\text { About Violence }\end{array}$ \\
\hline \multicolumn{6}{|c|}{ Students } \\
\hline$N$ & 49 & 48 & 49 & 46 & 45 \\
\hline$M$ & 3.84 & 5.29 & 3.22 & 3.76 & 4.67 \\
\hline$S D$ & 1.65 & 1.24 & 1.81 & 1.75 & 1.52 \\
\hline \multicolumn{6}{|c|}{ Parents } \\
\hline$N$ & 40 & 41 & 39 & 39 & 39 \\
\hline$M$ & 3.83 & 5.71 & 4.82 & 3.28 & 5.41 \\
\hline$S D$ & 2.02 & 0.75 & 1.82 & 2.11 & 1.07 \\
\hline \multicolumn{6}{|c|}{ Teachers } \\
\hline$N$ & 31 & & 35 & & 35 \\
\hline$M$ & 3.14 & & 5.23 & & 5.37 \\
\hline$S D$ & 1.85 & & 1.35 & & 0.91 \\
\hline
\end{tabular}

\section{How Did Participation in DtWT Impact Participants?}

\section{Survey Results}

Table 2 shows mean responses on the program impact scales of relationships and empathy. Participants responded positively regarding the impact of DtWT, with all mean scores falling above the mid-point of 3.5 on a 6-point scale, and parents responding most positively. Looking at impact on relationships, all three groups differed significantly. Parents responded more positively than teachers, who in turn were more positive than students, who were less likely to report improved 
relationships with parents and friends. All participants were very positive about the impact of the program on empathy for those who have experienced violence, with all means above 5. Parents were significantly more positive than students and significantly more positive than teachers, whereas students and teachers did not differ.

Table 2: Impact of Do the Write Thing on Participants' Experiences

\begin{tabular}{lccc} 
Group & Relationships abc & Empathyc & $\begin{array}{c}\text { Commitment to } \\
\text { Address Violence }^{\mathrm{a}}\end{array}$ \\
\hline Students & & & \\
$N$ & 40 & 44 & 45 \\
$M$ & 3.72 & 5.28 & 5.04 \\
$S D$ & 1.08 & 0.61 & 1.02 \\
Parents & & & \\
$N$ & 35 & 35 & 36 \\
$M$ & 5.03 & 5.63 & 5.62 \\
$S D$ & 0.75 & 0.46 & 0.70 \\
Teachers & & & 35 \\
$N$ & 35 & 35 & 5.30 \\
$M$ & 4.40 & 5.11 & 0.67 \\
$S D$ & 0.83 & 0.68 & \\
\hline
\end{tabular}

${ }^{a}$ Significant mean difference $(p<.05)$ between students and parents. ${ }^{b}$ Significant mean difference $(p<.05)$ between students and teachers. ${ }^{c}$ Significant mean difference $(p<.05)$ between parents and teachers.

\section{Findings From Focus Groups}

A deeper understanding of program impacts is gleaned by presenting themes and patterns that emerged from analysis of focus groups, looking first at personal impact and then impact on school and/or home. Selected quotes in the text illuminate these themes and patterns and provide detail and explanation to the reporting. Tables 3 through 5 present examples of all of the affective, behavioral, and cognitive themes for students, parents, and teachers that emerged from analyses of the transcriptions. 
Table 3: Themes Illustrating Affective Impact of the Program on Participants

\begin{tabular}{|c|c|c|c|}
\hline \multirow[b]{2}{*}{ Theme } & \multicolumn{3}{|c|}{ Sample Statements } \\
\hline & Students & Parents & Teachers \\
\hline Empathy & $\begin{array}{l}\text { Now I can view } \\
\text { things in [others] } \\
\text { point of view and } \\
\text { my point of view } \\
\text { and someone else's } \\
\text { point of view. }\end{array}$ & $\begin{array}{l}\text { When I read my son's essay, I } \\
\text { was blown away. I actually } \\
\text { cried because I just couldn't } \\
\text { believe the amount of } \\
\text { respect written on paper. }\end{array}$ & $\begin{array}{l}\text { Just reading the poems or } \\
\text { the essays was just very, } \\
\text { wow, these kids are really } \\
\text { going through a tough } \\
\text { time. }\end{array}$ \\
\hline Sympathy & $\begin{array}{l}\text { I've learned that } \\
\text { thinking more } \\
\text { about the victim } \\
\text { makes me feel sad } \\
\text { about them. }\end{array}$ & $\begin{array}{l}\text { I lost my brother and that's } \\
\text { what she wrote about and } \\
\text { for me this was a way to } \\
\text { honor my brother, and I just } \\
\text { cried... It's helped me and } \\
\text { it's helped her I mean we're } \\
\text { still healing from them, you } \\
\text { can't really fully heal from } \\
\text { wounds of a tragedy. }\end{array}$ & $\begin{array}{l}\text { I didn't understand how } \\
\text { much kids take things } \\
\text { internally. A lot of } \\
\text { depression. A lot of } \\
\text { suicidal thoughts or self- } \\
\text { harm. That really made } \\
\text { me sad as a person to see } \\
\text { it, so there is a lot more } \\
\text { than I had thought. }\end{array}$ \\
\hline
\end{tabular}

Table 4: Themes Illustrating Behavioral Impact of the Program on Participants

\begin{tabular}{|c|c|c|c|}
\hline \multirow[b]{2}{*}{ Theme } & \multicolumn{3}{|c|}{ Sample Statements } \\
\hline & Students & Parents & Teachers \\
\hline $\begin{array}{l}\text { Empower- } \\
\text { ment }\end{array}$ & $\begin{array}{l}\text { Motivated me more } \\
\text { to try and stop } \\
\text { youth violence and } \\
\text { help in any way I } \\
\text { could. }\end{array}$ & $\begin{array}{l}\text { It also made me want to be } \\
\text { more involved in the school, } \\
\text { but there is a lot to be done } \\
\text { still, and how we as parents } \\
\text { can assist the kids reach } \\
\text { their highest potential. }\end{array}$ & $\begin{array}{l}\text { It gave me a more complete } \\
\text { picture of the student as an } \\
\text { individual, and it helped me } \\
\text { be able to make } \\
\text { differentiations in my } \\
\text { attitude or my instruction } \\
\text { based on individual needs of } \\
\text { that student. }\end{array}$ \\
\hline Supportive & $\begin{array}{l}\text {...opened up to me to } \\
\text { try to get the } \\
\text { bullies to stop. }\end{array}$ & $\begin{array}{l}\text { We definitely are trying to be } \\
\text { better parents because we } \\
\text { know that these things } \\
\text { happen. }\end{array}$ & $\begin{array}{l}\text { Talk to other teachers and } \\
\text { say, this kid, be a little } \\
\text { careful. Be a little less } \\
\text { confrontational to get them } \\
\text { back on task. Little things } \\
\text { like that. }\end{array}$ \\
\hline $\begin{array}{l}\text { Communi- } \\
\text { cation }\end{array}$ & $\begin{array}{l}\text { Now instead of } \\
\text { fighting I talk } \\
\text { things out, and I } \\
\text { don't resort to } \\
\text { fighting anymore. } \\
\text { Me and my mom } \\
\text { talk about } \\
\text { handling stuff in a } \\
\text { different way. }\end{array}$ & $\begin{array}{l}\text { Being a part of all this has } \\
\text { helped open up the } \\
\text { conversation in general for } \\
\text { me with my kids and } \\
\text { working in schools, opening } \\
\text { those conversations with } \\
\text { the students I work with. }\end{array}$ & $\begin{array}{l}\text { Not just to be able to connect } \\
\text { with my students, but the } \\
\text { students to be able to } \\
\text { connect with each other and } \\
\text { with myself because I was } \\
\text { also able to share some } \\
\text { personal stories. }\end{array}$ \\
\hline
\end{tabular}


Table 5: Themes Illustrating Cognitive Impact of the Program on Participants

\begin{tabular}{|c|c|c|c|}
\hline \multirow[b]{2}{*}{ Theme } & \multicolumn{3}{|c|}{ Sample Statements } \\
\hline & Students & Parents & Teachers \\
\hline Tolerance & $\begin{array}{l}\text { It makes you think } \\
\text { differently about } \\
\text { like how others } \\
\text { feel when you, } \\
\text { when they are } \\
\text { violated. }\end{array}$ & $\begin{array}{l}\text { Just let them be, whatever } \\
\text { they want to be. That's } \\
\text { how it has impacted me. }\end{array}$ & $\begin{array}{l}\text { Do the Write Thing provides a } \\
\text { platform upon which teachers } \\
\text { can discuss some of these } \\
\text { issues in class...issues } \\
\text { involving racism, and } \\
\text { attitudes involving other } \\
\text { people At least I try to stress } \\
\text { in my interpretation of } \\
\text { history is tolerance versus } \\
\text { intolerance. }\end{array}$ \\
\hline Efficacy & $\begin{array}{l}\text { I know how to help } \\
\text { people. }\end{array}$ & $\begin{array}{l}\text { As a parent, I have to pat } \\
\text { myself on the back } \\
\text { because I know I'm doing } \\
\text { the right thing. }\end{array}$ & $\begin{array}{l}\text { It helps so you can know what } \\
\text { kind of kid you have and how } \\
\text { you can accommodate to help } \\
\text { because sometimes, like the } \\
\text { poet said, these kids are in } \\
\text { silence. }\end{array}$ \\
\hline $\begin{array}{l}\text { Helpless- } \\
\text { ness }\end{array}$ & $\begin{array}{l}\text { I felt so horrible that } \\
\text { I couldn't be there } \\
\text { to do anything } \\
\text { about it. }\end{array}$ & $\begin{array}{l}\text { They are exposed to a lot } \\
\text { more things that they } \\
\text { probably shouldn't be and } \\
\text { we never were, just } \\
\text { because of limitations in } \\
\text { technology and they are. } \\
\text { But we've got to deal with } \\
\text { that. }\end{array}$ & \\
\hline $\begin{array}{l}\text { Perspec- } \\
\text { tive }\end{array}$ & $\begin{array}{l}\text { It's a more effective } \\
\text { way of getting } \\
\text { ideas from people } \\
\text {...and because } \\
\text { there's emotion in } \\
\text { there instead of } \\
\text { just saying a story } \\
\text { and hearing it } \\
\text { from the news... } \\
\text { from a personal } \\
\text { account it's much } \\
\text { more effective. }\end{array}$ & $\begin{array}{l}\text { You don't realize how much } \\
\text { pressure a child can be } \\
\text { under. Whether it's just to } \\
\text { fit in, or to get good } \\
\text { grades. Just a number of } \\
\text { things. This has been an } \\
\text { eye opener. }\end{array}$ & $\begin{array}{l}\text { You feel like you know your } \\
\text { student ... when you read } \\
\text { these essays, there is a whole } \\
\text { other level, like it's an } \\
\text { iceberg. You see the tip, but } \\
\text { don't realize there is so much } \\
\text { more going on underneath } \\
\text { that it makes you just look at } \\
\text { them in a different way. }\end{array}$ \\
\hline $\begin{array}{l}\text { Complex- } \\
\text { ity }\end{array}$ & $\begin{array}{l}\text { It helped me } \\
\text { understand more } \\
\text { of how people are } \\
\text { affected. I know } \\
\text { that there is } \\
\text { physical violence } \\
\text { but there is } \\
\text { technology and } \\
\text { cyber bullying } \\
\text { now. }\end{array}$ & $\begin{array}{l}\text { I always knew the impact of } \\
\text { violence on kids, but at } \\
\text { such a young age, and the } \\
\text { different kinds, like the } \\
\text { gentleman spoke of today } \\
\text { of the different kinds of } \\
\text { violence that there are. }\end{array}$ & $\begin{array}{l}\text { Reading the essays helps me } \\
\text { see things that I didn't see or } \\
\text { didn't want to see or didn't } \\
\text { know how to address in my } \\
\text { classroom or in the school in } \\
\text { general. }\end{array}$ \\
\hline
\end{tabular}




\section{Personal Impact}

In terms of affective response, we found that students expressed greater empathy and sympathy for victims of violence and greater understanding of the impact and nuances of violence. Behaviorally, they tended to be more motivated to intervene, particularly when other students were being bullied. Cognitively, they expressed having more tolerance for differences, were less judgmental of others, and had gained new perspectives about violence and a greater awareness of violence, especially related to their own experiences. One student shared,

The main reason that I wrote [my essay] was because my uncle was shot and killed only a couple of years earlier. So the violence affected me in a really big way. I really wanted to tell others on how that affects the family and mentally scar people that have had their loved ones taken away so terribly at such a young age.

Students also reported communicating more with peers and family members instead of reverting to violence. They were empowered in feeling they could make a difference, and had gained a greater sense of the complexity of what violence is all about.

Parents reported increased understanding of violence in general in their schools and communities. They had greater understanding and awareness of the specific impacts of violence on their children. As a result, they felt closer to their children and reported increased communication and improved relationships with them. Many of their responses used language that evoked "eye-opening" experiences, both affective and cognitive. In the words of one parent,

You know there are certain things going on, and you know it does impact your kids, but just to see how they can articulate about how they actually feel...you don't realize how much pressure a child can be under. Whether it's to fit in, or to get good grades, just a number of things. This has been an eye opener.

Teachers gained knowledge about their students that led to changes in their attitudes toward students and instruction. They used the program as a platform to discuss issues associated with violence. They also saw that their students had become more tolerant, less discriminatory, and less hostile toward others (e.g., gender orientation and racial differences). The discussions and writing activities gave them new insight in helping students take different perspectives. Through discussions and writing, they became aware of their students' naiveté that led to urgency for helping them open their eyes. As a result, they expressed greater understanding and compassion toward their students that allowed them to establish mutually trusting relationships. These themes are represented in one teacher's response to the question of personal impact:

I was really affected by what my students wrote about themselves. We live in a low socioeconomic area and my school has over eighty percent who get free and reduced lunch. I think ok, its poverty. It's tough. I had students write about people close to them being shot and killed, and it made me look and think. So my students are sitting here worried about how I make them learn about nouns and verbs and they are really thinking about who is in jail and who is dead. So it gave me a much wider perspective on my purpose as an English teacher. I adjust my focus and priorities in the classroom when I have so many students with real violence or bullying. How in depth do I get with my nouns and verbs and sentence structure you know? It really helped 
me to reprioritize. They are people, not just kids getting information in their heads.

In summary, participants' responses supported survey results, but also provided a more in-depth perspective on how the program had impacted them personally. Particularly noteworthy in these results was the experience of the teachers. Not only did they feel that they had improved relationships with their students, but they also had gained new insight into their teaching strategies and important outcomes for their students.

\section{Impact on School/Home}

Tables 6 through 8 present examples of all of the affective, behavioral, and cognitive themes for students, parents, and teachers that emerged from analyses of the transcriptions. Many of the students reported more positive behaviors, more positive attitudes towards peers and teachers, and more positive relationships with teachers, peers, and family. They expressed hope that those who cause violence could learn from how people feel and change their behaviors. They were more motivated to talk to their teachers and report violence, encouraging others to do the same. Some were also more willing to step up and intervene to help others, and to talk things out rather than reverting to violence. One student noted, "It's affected me because now instead of fighting I talk things out, and I don't resort to fighting anymore. Me and my mom talk about handling stuff in a different way. That's why I want to be a psychologist." On the other hand, some students reported that not much had changed as a result of participating in the program, and this finding was in line with survey results. Although students overall were positive about improved relationships in the surveys, they were less positive than parents and teachers.

Table 6: Themes Illustrating Affective Impact of the Program on the School or Home

\begin{tabular}{|c|c|c|c|}
\hline \multirow[b]{2}{*}{ Theme } & \multicolumn{3}{|c|}{ Sample Statements } \\
\hline & Students & Parents & Teachers \\
\hline Empathy & $\begin{array}{l}\text { It changed things for me } \\
\text { because like now not } \\
\text { only can I see a wider } \\
\text { view of other people, } \\
\text { but my whole family } \\
\text { does, so they see other } \\
\text { people's stories and it } \\
\text { affects them as well in } \\
\text { a way. }\end{array}$ & $\begin{array}{l}\text { The way it's impacted me } \\
\text { at home, you just want } \\
\text { to really treat others as } \\
\text { you want to be treated. }\end{array}$ & $\begin{array}{l}\text {...a lot of them, like you guys } \\
\text { were saying that they } \\
\text { didn't know what violence } \\
\text { is or they can't relate. So, } \\
\text { once they hear someone's } \\
\text { story, they are like, "Oh my } \\
\text { god, I could relate," or "I } \\
\text { know what that means." }\end{array}$ \\
\hline Sympathy & $\begin{array}{l}\text { I had people like crying } \\
\text { in my arms when they } \\
\text { felt like this... and I } \\
\text { was like, "I don't think } \\
\text { I'm an average } \\
\text { person"... like, but it } \\
\text { was... it was like really } \\
\text { emotional and } \\
\text { touching... }\end{array}$ & $\begin{array}{l}\text { Violence is in different } \\
\text { shapes and forms, and } \\
\text {...we were looking at } \\
\text { some shoes, and she } \\
\text { [parent of a toddler] } \\
\text { smacked him really } \\
\text { hard to the point where } \\
\text { the little boy shook, and } \\
\text { it broke my heart. }\end{array}$ & $\begin{array}{l}\text { They will just be more aware } \\
\text { of when someone is hurting } \\
\text { or when somebody is } \\
\text { having trouble. They just } \\
\text { seem to be more } \\
\text { compassionate with each } \\
\text { other. }\end{array}$ \\
\hline
\end{tabular}


Table 7: Themes Illustrating Behavioral Impact of the Program on the School or Home

\begin{tabular}{|c|c|c|c|}
\hline \multirow[b]{2}{*}{ Theme } & \multicolumn{3}{|c|}{ Sample Statements } \\
\hline & Students & Parents & Teachers \\
\hline $\begin{array}{l}\text { Empower- } \\
\text { ment }\end{array}$ & $\begin{array}{l}\text { If I see my friends in a } \\
\text { fight, I'll try to break it } \\
\text { up because I don't want } \\
\text { them or the other person } \\
\text { getting in trouble or } \\
\text { getting them hurt. }\end{array}$ & $\begin{array}{l}\text { It has opened up the } \\
\text { dialogue...you can make an } \\
\text { impact, and you need to be a } \\
\text { leader, let your actions speak for } \\
\text { themselves...you have to care } \\
\text { about what happens. }\end{array}$ & $\begin{array}{l}\text { And they are } \\
\text { anxious to } \\
\text { participate } \\
\text { because it gives } \\
\text { them a voice. }\end{array}$ \\
\hline Support & $\begin{array}{l}\text { My parents are really } \\
\text { proud of me. They were } \\
\text { talking about it for } \\
\text { weeks and they would } \\
\text { not shut up. }\end{array}$ & $\begin{array}{l}\text { The other day at the grocery store, } \\
\text { my daughter saw someone push } \\
\text { a cart next to a car, and it was } \\
\text { very windy, and it was dashing } \\
\text { towards the car and she went } \\
\text { out and she grabbed it... and I } \\
\text { commented on that. }\end{array}$ & $\begin{array}{l}\text { They do believe in } \\
\text { sharing and } \\
\text { finding that } \\
\text { person that they } \\
\text { have that } \\
\text { relationship with } \\
\text { and that they } \\
\text { can trust. }\end{array}$ \\
\hline $\begin{array}{l}\text { Communi- } \\
\text { cation }\end{array}$ & $\begin{array}{l}\text { When I wrote it, most of } \\
\text { the time I was sitting in } \\
\text { the kitchen and its right } \\
\text { next to my mom's room } \\
\text { and she kept asking like, } \\
\text { "Why are you writing } \\
\text { that?" }\end{array}$ & $\begin{array}{l}\text { It taught me to just really } \\
\text { listen...we don't listen enough to } \\
\text { what our kids are having to say. }\end{array}$ & $\begin{array}{l}\text { The kids are more } \\
\text { open about } \\
\text { telling you } \\
\text { what's going on. }\end{array}$ \\
\hline
\end{tabular}


Table 8: Themes Illustrating Cognitive Impact of the Program on the School or Home

\begin{tabular}{|c|c|c|c|}
\hline \multirow[b]{2}{*}{ Theme } & \multicolumn{3}{|c|}{ Sample Statements } \\
\hline & Students & Parents & Teachers \\
\hline Tolerance & $\begin{array}{l}\text { It changes things for me } \\
\text { because...now I see a } \\
\text { wider view of other } \\
\text { people, but my whole } \\
\text { family...sees other } \\
\text { people's stories and it } \\
\text { affects them as well. }\end{array}$ & $\begin{array}{l}\text { But it's just being more } \\
\text { kind. That the way } \\
\text { it's impacted me at } \\
\text { home, you just want } \\
\text { to really want to treat } \\
\text { others as you want to } \\
\text { be treated. }\end{array}$ & $\begin{array}{l}\text { More tolerance. More } \\
\text { patience. Even from } \\
\text { teachers. }\end{array}$ \\
\hline Efficacy & $\begin{array}{l}\text { I feel that I can help them } \\
\text { more than I used to be } \\
\text { able, and feel like now } \\
\text { they feel like they can go } \\
\text { to other people, they can } \\
\text { go to the counselors and } \\
\text { talk to them and, the } \\
\text { counselors are more open } \\
\text { about it. }\end{array}$ & $\begin{array}{l}\text { We definitely are trying } \\
\text { to be better parents } \\
\text { because we know that } \\
\text { these things } \\
\text { happen... even my } \\
\text { wife has said, "I'm } \\
\text { going to be a better } \\
\text { parent because of } \\
\text { this." }\end{array}$ & $\begin{array}{l}\text { I see more compassion and } \\
\text { tolerance. They'll see an } \\
\text { incident and they will step } \\
\text { in or help out. They will } \\
\text { just be more aware of when } \\
\text { someone is hurting or when } \\
\text { somebody is having trouble. }\end{array}$ \\
\hline $\begin{array}{l}\text { Helpless- } \\
\text { ness }\end{array}$ & $\begin{array}{l}\text { Yes but it changed } \\
\text { nothing... My brother he's } \\
\text { younger and he's been } \\
\text { bullied and they've told } \\
\text { the teacher many times } \\
\text { and the principal many } \\
\text { times and they don't do } \\
\text { anything about it they } \\
\text { just laughed. }\end{array}$ & $\begin{array}{l}\text { I think these days it's } \\
\text { going to be hard to } \\
\text { address this because } \\
\text { people are "packing" } \\
\text { these days and you're } \\
\text { not going to be able to } \\
\text { approach anyone. }\end{array}$ & $\begin{array}{l}\text { When you hear from the } \\
\text { students, they feel like if } \\
\text { they say something, } \\
\text { nothing gets done. }\end{array}$ \\
\hline $\begin{array}{l}\text { Perspec- } \\
\text { tive }\end{array}$ & $\begin{array}{l}\text { My teacher made me write } \\
\text { the essay but I know } \\
\text { she's glad I did it because } \\
\text { this has helped me a lot } \\
\text { with my violence...so I'm } \\
\text { gonna tell all my friends } \\
\text { and the whole school and } \\
\text { principal to promote this } \\
\text { and to make this a bigger } \\
\text { deal than it is right now. }\end{array}$ & $\begin{array}{l}\text {... a little more aware of } \\
\text { things where we may } \\
\text { have just kind of } \\
\text { brushed things off } \\
\text { before but like I said } \\
\text { we had no idea how } \\
\text { this was affecting her. }\end{array}$ & $\begin{array}{l}\text { We had several students } \\
\text { write [about] an incident } \\
\text { that happened because one } \\
\text { of their classmates was } \\
\text { shot. His stepdad killed his } \\
\text { mother and his brother. So, } \\
\text { I think a lot of them did } \\
\text { feel that healing through } \\
\text { writing... where otherwise } \\
\text { they probably wouldn't } \\
\text { have prompted themselves } \\
\text { to write about it. }\end{array}$ \\
\hline $\begin{array}{l}\text { Complex- } \\
\text { ity }\end{array}$ & $\begin{array}{l}\text { So it really does take time } \\
\text { to get to the utmost high } \\
\text { level and you know we're } \\
\text { always going to be } \\
\text { growing. }\end{array}$ & $\begin{array}{l}\text { It makes you more } \\
\text { aware of gaps and the } \\
\text { generational gaps. }\end{array}$ & $\begin{array}{l}\text { I try to show them that } \\
\text { violence is not just } \\
\text { physical...there are other } \\
\text { things as well...I get them } \\
\text { started and I let them see } \\
\text { what they come up with. }\end{array}$ \\
\hline
\end{tabular}


Parents mostly addressed very positive changes in the home. They had become more aware of their child's concerns and needs. They expressed that communication with their child and their spouse had improved and they were working to become better parents. To illustrate, one parent shared this personal story:

It's definitely had an impact on my husband as well. He doesn't have a temper; he just has a weird man way of dealing with things. He's been more aware of how he actually relates to all of our children because of everything that has been going on in school. And him reading the essay, I think it brought out this extreme sense of pride in him that his son did that. Secondly, it kind of made him look at his son as more mature in his eyes. He's always been a straight A student, but his conduct when he went into the sixth grade went through the floor. But he is rebounding so it's been a good change, and I think this has actually allowed him to be able to take some personal accountability into a lot of things. For every little boy it's "I want my dad's approval." So, I think he feels he has that stamp and giving it to him he says, "Yes!"

Overall, parents felt that participation in DtWT had positively impacted their family and would like to see more schools and children involved in the program.

Some of the teachers saw greater tolerance and compassion in their students as a result of their discussions and essay writing. The following example is illustrative of comments about their students that we heard frequently:

I see more compassion on a personal level. It's kind of picking up on tolerance. They'll see an incident and they will step in or help out. They will just be more aware of when someone is hurting or when somebody is having trouble. They just seem to be more compassionate with each other.

Some also observed more healing and bonding in their students' families. They believed that DtWT provided a platform for recognition of students impacted by violence. Some also reported making changes in their teaching to begin early in discussing fears about violence and using writing as a preventive measure. Other teachers, like some of the students, did not see significant changes in their schools, but felt that it was due to insufficient time available for classroom writing and discussion activities.

To summarize, participants' responses supported survey results, but provided more in-depth perspective on how the program had impacted schools and/or homes. Specifically, level of impact appears to be related to the amount of time devoted to this project in the schools.

\section{What Were Participants Doing to Address Violence?}

\section{Survey Results}

Although survey questions did not address specific actions being taken to address violence, three questions assessed participants' commitment to reduce violence (see Table 2). All three groups were very positive about making a continued commitment to reduce violence, with all means above 5 . The groups were similar, but parents were significantly more positive than students. 


\section{Findings From Focus Groups}

Tables 9 through 11 present examples of all of the affective, behavioral, and cognitive themes for students, parents, and teachers that emerged from analyses of the transcriptions. Students communicated a new found awareness that they could do things differently rather than resort to violence. They were more often reporting bullying to teachers and other adults and were much more aware of the importance of doing so. Not only were they standing up for themselves as they gained confidence, but they were also reaching out to kids who didn't have friends and were often bullied. They reported defending and protecting these kids and trying to stop fights. One student shared this story:

My friend, she wasn't literally bullied, but she was just being teased by another person in my class and she was kind of annoyed by it, and sometimes when you are annoyed, you can't hide your emotions, so she was tearing up and I said, "Come here." I put her face in my shoulder. So when someone is sad, you should give them your shoulder to cry on and support them. I said, "It's going to be ok. I still love you. Don't worry about it."

Some of the students were also participating in other various antiviolence initiatives such as wearing bracelets (e.g., "Be a Buddy, Not a Bully") or t-shirts (e.g., "Be Kind").

Table 9: Themes Illustrating Affective Impact Related to Actions

\begin{tabular}{|c|c|c|c|}
\hline \multirow[b]{2}{*}{ Theme } & \multicolumn{3}{|c|}{ Sample Statements } \\
\hline & Students & Parents & Teachers \\
\hline Empathy & $\begin{array}{l}\text { Would try to talk with the person } \\
\text { being bullied because often people } \\
\text { focus so much on the person that } \\
\text { is doing the bullying and try to } \\
\text { stop them but they never realize } \\
\text { that the person being bullied is } \\
\text { more in mental trauma than the } \\
\text { person who actually did the } \\
\text { bullying. So I would actually try } \\
\text { to talk to the person who is being } \\
\text { bullied and just try to make them } \\
\text { feel like they are above that...like } \\
\text { they don't have to deal with that, } \\
\text { you know }\end{array}$ & $\begin{array}{l}\text { It's so easy; especially I think as a } \\
\text { kid to, kind of stand back and } \\
\text { giggle with the others or } \\
\text { participate in certain things. I } \\
\text { always tell them you never } \\
\text { know what is going on in } \\
\text { another person's life. This might } \\
\text { be this child's escape } 8 \text { hr a day, } \\
\text { because you don't know what is } \\
\text { going g on at home. If you see } \\
\text { something you want to help } \\
\text { shelter that person, or you want } \\
\text { to help defend that person. }\end{array}$ & \\
\hline Sympathy & $\begin{array}{l}\text { I put her face in my shoulder. So } \\
\text { when someone is sad, you should } \\
\text { give them your shoulder to cry on } \\
\text { and support them. If someone is in } \\
\text { need, even if I don't know them, I } \\
\text { will go up to them. }\end{array}$ & $\begin{array}{l}\text { She gave him a nice big one, } \\
\text { smacked him really hard to the } \\
\text { point where the little boy shook, } \\
\text { and it broke my heart. And until } \\
\text { now it makes me feel really bad, } \\
\text { and I told my husband. His first } \\
\text { response was, don't say } \\
\text { anything but this reminded me } \\
\text { that I had to be a voice for that } \\
\text { little boy. I went over there and } \\
\text { said, "Do you mind? I want to } \\
\text { just talk to you." }\end{array}$ & \\
\hline
\end{tabular}


Table 10: Themes Illustrating Behavioral Impact Related to Actions

\begin{tabular}{|c|c|c|c|}
\hline \multirow[b]{2}{*}{ Theme } & \multicolumn{3}{|c|}{ Sample Statements } \\
\hline & Students & Parents & Teachers \\
\hline $\begin{array}{l}\text { Empower- } \\
\text { ment }\end{array}$ & $\begin{array}{l}\text { I would try to walk over } \\
\text { and defend the other } \\
\text { person and make them } \\
\text { stop. }\end{array}$ & $\begin{array}{l}\text { I want to help, that is what } \\
\text { it takes. A team of people } \\
\text { like yourselves...make a } \\
\text { big banner for the school } \\
\text { indicating this is a no } \\
\text { bully zone... Make shirts } \\
\text { and pass them out so that } \\
\text { everyone can be impacted } \\
\text { and know that it's around } \\
\text { here. }\end{array}$ & $\begin{array}{l}\text { I tell them that you have } \\
\text { to stand up for yourself. } \\
\text { If you need to speak to } \\
\text { the principal because } \\
\text { your mom can't, then } \\
\text { stand up and tell } \\
\text { them...if you need us to } \\
\text { come and talk to } \\
\text { someone, but you do it. }\end{array}$ \\
\hline Support & $\begin{array}{l}\text { If someone wants to show } \\
\text { me a video, I'm going to } \\
\text { say "No, that is } \\
\text { disrespectful." I don't } \\
\text { want to watch someone } \\
\text { else's embarrassment } \\
\text { just for pleasure. }\end{array}$ & $\begin{array}{l}\text { I talk to my son about } \\
\text { stepping in when you see } \\
\text { things going on in school. }\end{array}$ & $\begin{array}{l}\text { I have a very strong } \\
\text { presence with the kids } \\
\text {... we have to be very, } \\
\text { you know, engaging the } \\
\text { kids because they are } \\
\text { watching you whether } \\
\text { you are realizing or not. } \\
\text { So, you have to make } \\
\text { sure that you are a } \\
\text { model behavior. }\end{array}$ \\
\hline $\begin{array}{l}\text { Communi- } \\
\text { cation }\end{array}$ & $\begin{array}{l}\text { I go to a very ghetto school } \\
\text { so I'm trying my hardest } \\
\text { to do all that stuff. It's } \\
\text { coming along. Smaller } \\
\text { people are starting to } \\
\text { speak up. Not fight back } \\
\text { but to defend themselves } \\
\text { with words, and talking } \\
\text { them out, and walking } \\
\text { away from bullies, and } \\
\text { taking themselves out of } \\
\text { situations like that. }\end{array}$ & $\begin{array}{l}\text { I've been trying to voice } \\
\text { more to my children to be } \\
\text { more of a voice for others. } \\
\text { They've raised concerns } \\
\text { about what if it comes } \\
\text { back to me. I said, well, } \\
\text { you still need to speak up. } \\
\text { You still need to call it } \\
\text { out. }\end{array}$ & $\begin{array}{l}\text { We talk about respect for } \\
\text { everyone including } \\
\text { racial slurs toward our } \\
\text { own group and other } \\
\text { groups...I talk more } \\
\text { about historical, social } \\
\text { and economic class } \\
\text { violence. Teach them } \\
\text { respect and kindness. }\end{array}$ \\
\hline
\end{tabular}


Table 11: Themes Illustrating Cognitive Impact Related to Actions

\begin{tabular}{|c|c|c|c|}
\hline \multirow[b]{2}{*}{ Theme } & \multicolumn{3}{|c|}{ Sample Statements } \\
\hline & Students & Parents & Teachers \\
\hline Tolerance & $\begin{array}{l}\text { Now I don't resort } \\
\text { to violence, and I } \\
\text { take my time, and } \\
\text { I don't get overly } \\
\text { upset and I help } \\
\text { out people, and I } \\
\text { stand up for } \\
\text { justice. }\end{array}$ & $\begin{array}{l}\text { Because you don't know what } \\
\text { kids are going through. Just } \\
\text { being a safe loving adult who } \\
\text { listens to them. Just provide } \\
\text { that for them I guess. }\end{array}$ & $\begin{array}{l}\text { Teach them respect and } \\
\text { kindness that we just work it } \\
\text { and we all do it all the time. }\end{array}$ \\
\hline Efficacy & $\begin{array}{l}\text { I can do things } \\
\text { differently without } \\
\text { using as much } \\
\text { violence. }\end{array}$ & $\begin{array}{l}\text { I'm going to meet with Chair } \\
\text { and a nonprofit organization } \\
\text { in our town... about opening a } \\
\text { recreational center to have a } \\
\text { program. }\end{array}$ & $\begin{array}{l}\text {...one of the themes we picked } \\
\text { out was knowledge is a weapon } \\
\text { like the more you know the } \\
\text { better you know the more } \\
\text { powerful you are and that } \\
\text { violence is the tool to ignorant } \\
\text { people who don't get it. }\end{array}$ \\
\hline $\begin{array}{l}\text { Perspec- } \\
\text { tive }\end{array}$ & $\begin{array}{l}\text { I'm like thinking } \\
\text { about how I can do } \\
\text { things differently } \\
\text { without using as } \\
\text { much like violence } \\
\text { as I can possibly } \\
\text { do. }\end{array}$ & $\begin{array}{l}\text { See our generation, our peers } \\
\text { we couldn't voice anything. So } \\
\text { therefore we carry that on, be } \\
\text { quiet, you don't have a voice } \\
\text { in this house, but times are } \\
\text { changing. You know so we're } \\
\text { going to have to change } \\
\text { somewhat I guess. }\end{array}$ & $\begin{array}{l}\text { In all honesty, I stopped } \\
\text { pitying my students. I stopped } \\
\text { feeling bad for them just } \\
\text { because they knew someone } \\
\text { that got shot, that got killed, } \\
\text { and that was a drug dealer } \\
\text { that participated in a drive by } \\
\text { shooting. I stopped pitying } \\
\text { them and I started holding } \\
\text { them accountable. }\end{array}$ \\
\hline
\end{tabular}

Parents reported monitoring their children more closely in their neighborhoods to see what they were doing. They were involved in activities such as church programs that teach kids how to intervene for others. Many reported an interest in creating projects to help kids with problems related to violence but had not yet done so. Most of the responses, however, addressed more subtle differences in the way they talk with their children. For example,

I've been trying to voice more to my children to be more of a voice for others. They've raised concern about what if it comes back to me. I said well you still need to speak up. You still need to call it out. Bullies do not like to be called out. They do not like to be called a bully. It's really helped them break out of their shell, and to build a safe harbor of friends and teachers and a network of people, and I can bring that home too. I tell them, "Whatever happens in the world, you can always come home and it's a safe harbor. I will be here."

Teachers reported that they were integrating DtWT activities with other related programs in their schools. They were bringing up issues associated with bullying and violence in their classroom activities and discussions throughout the year and helping their students make connections to the classroom curriculum. An example of this was offered by a social studies teacher: 
Do the Write Thing provides a platform upon which teachers can discuss some of these issues in class. Even in a history class, we get into issues involving racism and attitudes involving other people. It's one of the major issues things we try to stress. At least I try to stress in my interpretation of history is tolerance versus intolerance. When we talk about the different kinds of movements in history, religious intolerance, racial intolerance, you can talk about the puritans, and the movements and history involving that. So, there is always room, I think, in almost any subject to bring those issues up.

They found that they were more closely monitoring student behavior regarding bullying and teaching their students not to be bystanders. On a personal level, they had become much more aware of having to model good behavior and teach values concerning interpersonal behaviors.

In summary, participants had made subtle but important changes in their own behaviors and their behaviors toward others as a result of increased awareness about violence. The most significant changes appeared to come from teachers, who changed behaviors such as monitoring students more closely in addition to changing their teaching activities. Because data was collected only a few months after the program was implemented in the schools, participants did not report being engaged in formal follow-up activities but some expressed interest in doing so.

\section{What Were Participants' Recommendations for Continuing Efforts to Reduce Violence?}

Several strong and consistent themes for recommendations emerged from all three groups of participants, with a majority of comments focused primarily on ways to expand and support the program. First, was the recommendation to "get the word out" to increase awareness of DtWT through enhanced publicity efforts in schools, homes, and communities. In the schools, participants noted that the program should include a broader range of students and activities to infuse and integrate it throughout the school curriculum, as well as to coordinate with other antiviolence or bullying initiatives. Students suggested expanding the expressive writing activity to include other artistic modalities, such as making videos, writing songs, or creating art projects, to generate more interest among students who are allowed to opt out of writing essays. Teachers specifically requested support for expanding and sharing additional curriculum resources and lesson plans. All of the participant groups believed it was important to expand the program not only in schools but also to extend it to increase parent involvement, as well as broadening community involvement. A frequent suggestion for program expansion was to add follow-up activities requiring ambassadors and semifinalists from each city to become active violence-prevention leaders in their schools and communities. Interestingly, the student ambassadors as well as teachers and parents attending National Recognition Week recommended that all participants in the program be acknowledged and congratulated through increased opportunities for recognition of participation. Of course all of these recommendations require increased resources, and participants almost unanimously recommended that more resources be provided to support these expansion efforts.

\section{Discussion}

Given the numbers of students who have experienced and/or witnessed violence and the negative impacts of violence on their lives, it is imperative that schools take action through antiviolence programs and that these programs be examined for effectiveness. Although DtWT has been in existence for 20 years, little formal research has been conducted to systematically examine its impact on participants. 
The first research question addressed students' motivation for writing essays. We were very encouraged that the most motivating factor for students was trying their best, followed by participating in classroom discussions about violence, a core element of the program. These results imply that the rewards for addressing issues of violence were more intrinsic than extrinsic (e.g., winning a "prize" in an essay competition) suggesting altruistic motives. Such motives are likely to be more sustainable and useful over time to facilitate ongoing efforts toward violence prevention. The least motivating factor was self-efficacy for writing, suggesting that the writing aspect of the program could be emphasized, so as to increase student's confidence and competence in writing, especially if writing has therapeutic importance. Together, these results suggest there is value in future research exploring how the program can enhance specific elements to influence students' motivation for writing their essays.

The second research question addressed the program's impact on individuals, schools, and families. Among the most salient outcomes were improved relationships between students and their peers, their teachers, and their family members as reflected in the surveys, as well as in the focus group themes of communication, support, tolerance, and perspective. Communication and building relationships between students and teachers are essential elements of DtWT which are crucial in the development of attachment and respect, each of which have been shown to affect aggression (Mayseless \& Scharf, 2011; Mikulincer \& Shaver, 2011). Thus, in future research, it would be worthwhile to examine in depth how the program facilitates and improves relationships and the impact of those changes in changing the culture of violence in schools and home.

One of the primary goals of DtWT is to help students understand the causes and impact of violence to help them take personal responsibility for reducing violence. This outcome was reflected in the surveys with very high mean responses to the empathy scale, as well as focus group themes of empathy, sympathy, support, tolerance, perspective, and complexity. Another important impact of the program was change and motivation to change, which was observed in the positive responses to the survey scale of commitment to address violence and throughout the focus groups. Many students reported that with increased understanding of their classmates' experiences with violence, they are responding differently or at least have the intention of responding differently when they know someone is being bullied or otherwise experiencing unfortunate incidents with violence. Some also reported changing their own behaviors when they were angry or engaged in bullying themselves. According to the reasoned action approach to behavior change (Fishbein \& Ajzen, 2010), an individual's intention to perform any given behavior is influenced by (a) the individual's attitude toward the outcome of a behavior, (b) the expectation to perform that behavior based on the normative expectations of relevant peers, and (c) the person's perceived capability (i.e., efficacy) to perform the behavior. Thus, it would be enlightening to examine the specific effects of DtWT program activities (e.g., discussion and writing) and cognitive outcomes (e.g., improved understanding, empathy, sympathy, and tolerance) on attitudes toward violence/ violence prevention, expectations of relevant peer groups regarding violence/violence prevention, participants' beliefs about their abilities to act to prevent violence, participants' intentions/commitments to act to prevent violence, and actual efforts enacted following participation. Exploring these dynamics can lend depth of insight to the existing research on school-based interventions and offer suggestions to improve the behavioral outcomes of DtWT and other violence prevention programs.

Perhaps the most meaningful and potentially long lasting impact was that teachers have changed their teaching as a result of participating in DtWT. Examples of these changes included individualizing instruction or making accommodations for certain students, as well as infusing learning activities related to violence throughout the school year. This is an important outcome because research has revealed that students are more likely to be favorable toward seeking help for 
bullying and threats of violence when they perceive teachers and staff to be supportive (Eliot et al., 2010). Research on school-based interventions has not typically addressed teachers' instructional practices as an outcome of the programs, but additional research should do so. For example, it would be informative to determine the elements of teaching (e.g., instructional practices, curriculum content, student-teacher relationships, etc.) that are most effective for reducing violence. Another important avenue to explore is teachers' beliefs about their roles in helping students address and reduce violence. Research has clearly established that teachers' beliefs influence their teaching practice (Fives \& Buehl, 2012). In addition, research on conceptual change and teacher efficacy implies that to be effective in this program, teachers must believe they can play an important role in helping students deal with violence (Turner, Warzon, \& Christensen, 2011), and they must believe that they are capable of doing so (Gregoire, 2003; Woolfolk Hoy, Davis, \& Pape, 2006).

In addition to the positive impacts identified above, there were also some inconsistent and mixed results on program impact, similar to previous research studies on school-based interventions (Fagan \& Catalano, 2012; Ttofi \& Farrington, 2011). Although we obtained strong evidence of positive outcomes for many participants, some students and teachers reported a lack of change in their classrooms and schools. In most of these cases, they also indicated that insufficient time and resources had been devoted to the program. Given the previous research findings showing that longer term and more intense interventions are more effective (Ttofi \& Farrington, 2011), it is not surprising that the program had less impact in schools that devoted less time to the program activities. Participants recognized that more time and resources for DtWT activities would be needed to fully realize the potential for this program and recommended such.

The third research question asked participants what they were doing specifically to reduce violence. All three groups of participants reported some specific actions they had started taking or changes they had made as a result of the program. Students offered numerous examples of changes in the way they understood and related to their peers, as well as reporting incidents. Others stated their intentions for changing the way they acted, but did not offer specific actions they had already taken. Parents noted differences in understanding, talking, and monitoring their children; some of the responses also referred to intentions to take action but participants had not yet done so. Teachers offered numerous ways in which they had made changes in their teaching. On the other hand, most participants did not report taking specific steps to become involved in activities involving the broader community, which is one of the five DtWT program elements. Because the National Recognition Week took place only 2 months after ambassadors were selected, it is possible that not enough time had passed to initiate follow-up activities. Nonetheless, these mixed results suggest the need for careful attention to fidelity of program implementation, specifically addressing activities involving the larger community. A strong theme in participants' recommendations for the program was the need for providing resources to support this type of involvement with the community, leading to the fourth research question.

In response to the fourth research question concerning participants' recommendations for the program, responses reflected how highly participants valued the program and the opportunities it had provided, while also suggesting they were very aware of the need for additional resources and expanded activities to realize its full potential. Based on the research identifying effective elements of bullying interventions, additional resources could be used to lengthen the program and to institute parent involvement through training and meetings. These enhancements are supported by Epstein and Sheldon's (2006) work, which emphasizes the need for collaborative relationships of parents, educators, and community partners to identify common goals for students' academic achievement and to appreciate each other's contribution to student development. In addition, teachers could be 
supported with the development of additional instructional resources such as videos and cooperative activities that have been shown to be effective (Ttofi \& Farrington, 2011).

In summary, results provide support for the realization of three of the five elements of DtWT, namely writing essays about violence, creating open lines of communication between students and teachers, and providing schools with information from students' essays not otherwise readily available. Results were less clear for the element of students accepting personal responsibility for saying no to violence. Future research should focus on measuring observable impacts on students' behaviors, incidents of bullying/violence, school climate, and longer term outcomes. The fifth program element is giving students the opportunity to share their ideas and solutions with community members and policy makers (e.g., elected officials, family court judges, business leaders, etc.). Although a few participants mentioned these activities, the evidence regarding opportunities to engage the community was not compelling.

This study had several limitations. First, the sample was limited to participants who were selected to attend National Recognition Week in Washington DC which may not be representative of everyone who was involved in DtWT activities during the school year. They may be biased toward having more positive attitudes toward the program. In addition, we did not have specific information about how the program had been implemented in each of the students' participating schools, so we were not able to interpret our results in relation to specific program implementation, beyond selfreports of the participants. Third, we were unable to administer pre- and postmeasures of outcomes, so inferences about change are based on self-reports of the participants. In spite of these limitations, the mixed methods used in this study provide compelling and important evidence for the value of this large-scale program and the potential benefits of expanding it and infusing additional resources.

In addition to specific recommendations for future research already mentioned, there is clearly a need for large-scale research to be conducted in the schools. An important and potentially fruitful direction for future research is to pursue a deeper understanding of the effects of writing, including the types and content of that writing, on students' experiences with violence and their intentions and efforts to prevent violence. Specifically, how does discussion and writing about their experiences with violence affect (a) students' attitudes about violence and aggressive behaviors, (b) perceived group norms around aggressive and violent behaviors, and (c) perceived ability to control aggressive or violent behaviors of self or others? If proven beneficial to influence these factors, it would provide support for expanding the writing component of this program.

The reasoned action approach (Fishbein \& Ajzen, 2010) also indicates that there may be factors, not under a person's immediate volitional control, that could prohibit action, even if intentions to do so are strong. Thus, a second significant area of research would be to explore specific external barriers (e.g., school policies, lack of support, parental attitudes, access to resources, limited repertoires of behavioral skills, etc.) to violence prevention action faced by DtWT participants, which could lead to identification and development of additional tools needed to facilitate engagement in violence prevention activities. Although such barriers and possible remedies may be situation specific, identification of general patterns could be useful.

Finally, using a variety of research methods can provide unique but complementary insights. In addition to well-controlled quantitative studies focused on outcome data, methods such as comprehensive program evaluations, qualitative methods such as case studies and ethnographies, and replications across diverse populations would lend deeper insight into the effectiveness of violence prevention efforts. 


\section{References}

Armsworth, M. W., \& Holaday, M. (1993). The effects of psychological trauma on children and adolescents. Journal of Counseling \& Development, 72, 49-56.

Beck, A. B. (2013). An econometric analysis of anti-bullying program factors on bullying in public American middle schools and high schools. Undergraduate Economic Review, 9, 1-12.

Crooks, C. V., Scott, K., Ellis, W., \& Wolfe, D. A. (2011). Impact of a universal school-based violence prevention program on violent delinquency: Distinctive benefits for youth with maltreatment histories. Child Abuse \& Neglect, 35, 393-400. doi:10/1016/j.chiabu.2011.03.002

Eliot, M., Cornell, D., Gregory, A., \& Fan, X. (2010). Supportive school climate and student willingness to seek help for bullying and threats of violence. Journal of School Psychology, 48, 533-553. doi:10.1016/j.jsp.2010.07.001

Epstein, J. L., \& Sheldon, S. B. (2006). Moving forward: Ideas for research on school, family, and community partnerships. In C. F. Conrad \& R. C. Serlin (Eds.), The SAGE handbook for research in education (pp. 117-137). Thousand Oaks, CA: Sage.

Fagan, A. A., \& Catalano, R. F. (2012). What works in youth violence prevention: A review of the literature. Research on Social Work Practice, 23, 141-156. doi:10/1177/1049731512465899

Farrell, A. D., Mehari, K. R., Kramer-Kuhn, A. M., Mays, S. A., \& Sullivan, T. N. (2015). A qualitative analysis of factors influencing middle school students' use of skills taught by a violence prevention curriculum. Journal of School Psychology, 53, 179-194. doi:10/1016/j.jsp.2015.03.991

Fingar, K. R., \& Jolls, T. (2014). Evaluation of a school-based violence prevention media literacy curriculum. Injury Prevention, 20, 183-190. doi:10.1136/injuryprev-2013-040815

Finkelhor, D., Turner, J., Ormrod, R., Hamby, S., \& Kracke, K. (2009, October). Children's exposure to violence: A comprehensive national survey. Juvenile Justice Bulletin, Office of Juvenile Justice and Delinquency Prevention. Washington, DC: U.S. Department of Justice. Retrieved from www.ojp.usdoj.gov

Fishbein, M., \& Ajzen, I. (2010). Predicting and changing behavior: The reasoned action approach. New York, NY: Psychology Press.

Fives, H., \& Buehl, M. M. (2012). Spring cleaning for the "messy" construct of teachers' beliefs: What are they? Which have been examined? What can they tell us? In K. R. Harris, S. Graham, \& T. Urdan (Eds.), APA educational psychology handbook: Vol. 2. Individual differences and cultural and contextual factors. Washington, DC: American Psychological Association.

Fowler, P. J., Tompsett, C. J., Braciszewski, J. M., Jacques-Tiura, A. J., \& Baltes, B. B. (2009). Community violence: A meta-analysis on the effect of exposure and mental health outcomes of children and adolescents. Development and Psychopathology, 21, 227-259. doi:10.1017/S0954579409000145

Giannotta, F., Settanni, M., Kliewer, W., \& Ciairano, S. (2009). Results of an Italian school-based expressive writing intervention trial focused on peer problems. Journal of Adolescence, 32, 1377-1389. doi:10.1016/j.adolescence.2009.07.001

Gregoire, M. (2003). Is it a challenge or a threat? A dual-process model of teachers' cognition and appraisal processes during conceptual change. Educational Psychology Review, 15, 147-179. 
Holt, S., Buckley, H., \& Whelan, S. (2008). The impact of exposure to violence on children and young people: A review of the literature. Child Abuse \& Neglect, 32, 797-810.

doi:10.1016/j.chiabu.2008.02.004

Hymel, S., \& Swearer, S. M. (2015). Four decades of research on school bullying. American Psychologist, 70, 293-299. http://dx.doi.org/10.1037/a0038928

Jagers, R. J., Morgan-Lopez, A. A., Flay, B. R., \& Aban Aya Investigators. (2009). The impact of age and type of intervention on youth behaviors. Journal of Primary Prevention, 30, 642-658. doi:10/1007/s10935-009-0200-1

Jaycox, L. H., McCaffrey, D., Eiseman, B., Aronoff, J., Shelley, G. A., Collins, R. L., \& Marshall, G. N. (2006). Impact of a school-based dating violence prevention program among Latino teens: Randomized controlled effectiveness trial. Journal of Adolescent Health, 39, 694-704. doi:10.1016/j.jadohealth.2006.05.002

Kliewer, W., Lepore, S. J., Farrell, A. D., Allison, K. W., Meyer, A. L., Sullivan, T. N., \& Greene, A. Y. (2011). A school-based expressive writing intervention for at-risk urban adolescents' aggressive behavior and emotional lability. Journal of Clinical Child \& Adolescent Psychology, 40, 683-705. doi:10.1080/15374416.2011.597092

La Rue, L., Polanin, J. R., Espelage, D. L., \& Pigott, T. D. (2016). A meta-analysis of school-based interventions aimed to prevent or reduce violence in teen dating relationships. Review of Educational Research. Advance online publication. doi:10.3102/0034654316632061

Margolin, G., \& Gordis, E. (2000). The effects of family and community violence on children. Annual Review of Psychology, 51, 445-479.

Margolin, G., \& Gordis, E. (2004). Children's exposure to violence in the family and community. Current Directions in Psychological Science, 13, 152-155.

Mayseless, O., \& Scharf, M. (2011). Respecting others and being respected can reduce aggression in parent-child relations and in schools. In P.R. Shaver \& M. Mikulincer (Eds.) Human aggression and violence: Causes, manifestations, and consequences (pp. 277-294). Washington, DC: American Psychological Association.

McDougall, P., \& Vaillancourt, T. (2015). Long-term adult outcomes of peer victimization in childhood and adolescence. American Psychologist, 70, 300-310. doi:10.1037/a0039174

McWhirter, J. J., McWhirter, B. T., McWhirter, E. H., \& McWhirter, R. J. (2013). At risk youth: A comprehensive response for counselors, teachers, psychologists, and human service professionals (5th ed.). Belmont, CA: Brooks Cole.

Mikulincer, M., \& Shaver, P. R. (2011). Attachment, anger, and aggression. In P. R. Shaver \& M. Mikulincer (Eds.), Human aggression and violence: Causes, manifestations, and consequences (pp. 241-257). Washington, DC: American Psychological Association.

National Education Association. (2012, October 8). Nation's educators continue push for safe, bullyfree environments. Retrieved from http://www.nea.org/home/53298.htm

Shank, G. (2002). Qualitative research: A personal skills approach. Upper Saddle River, NJ: Merrill Prentice Hall.

Shuval, K., Pillsbury, C. A., Cavanaugh, B., McGruder, L., McKinney, C. M., Massey, Z., \& Groce, N. E. (2010). Evaluating the impact of conflict resolution on urban children's violence-related attitudes and behaviors in New Haven, Connecticut, through a community-academic partnership. Health Education Research, 25, 757-768. doi:10.1093/her/cyq030 
Ttofi, M. M., Bowes, L., Farrington, D. P., \& Losel, F. (2014). Protective factors interrupting the continuity from school bullying to later internalizing and externalizing problems: A systematic review of prospective longitudinal studies. Journal of School Violence, 13, 5-38. doi:10.1080/15388220.2013.857345

Ttofi, M. M., \& Farrington, D. P. (2011). Effectiveness of school-based programs to reduce bullying: A systematic and meta-analytic review. Journal of Experimental Criminology, 7, 27-56. doi:10.1007/s10935-009-0200-1

Turner, J. C., Warzon, K. G., \& Christensen, A. (2011). Motivating mathematics learning: Changes in teachers' practices and beliefs during a nine-month collaboration. American Educational Research Journal, 48, 718-761.

Woolfolk Hoy, A., Davis, H., \& Pape, S. J. (2006). Teacher knowledge and beliefs. In P. Alexander \& P. Winne (Eds.), Handbook of educational psychology (2nd ed.). Mahway, NJ: Lawrence Erlbaum.

Zona, K., \& Milan, S. (2011). Gender differences in the longitudinal impact of exposure to violence on mental health in urban youth. Journal of Youth and Adolescence, 40, 1674-1690. doi:10.1007/s10964-011-9649-3

Zucker, M., Spinazzola, J., Pollack, A. A., Pepe, L., Barry, S., Zhang, L., \& Van der Kolk, B. (2010). Getting teachers in on the act: Evaluation of a teacher- and classroom-based youth violence prevention program. Journal of School Violence, 9, 117-135. doi:10.1080/15388220903479628

The Journal of Educational Research and Practice provides a forum for studies and dialogue that allows readers to better develop social change in the field of education and learning. Journal content may focus on educational issues of all ages and in all settings. It also presents peer-reviewed commentaries, book reviews, interviews of prominent individuals, and additional content. The objectives: We publish research and related content that examines current relevant educational issues and processes aimed at presenting readers with knowledge and showing how that knowledge can be used to impact social change in educational or learning environments. Additional content provides an opportunity for scholarly and professional dialogue regarding that content's usefulness in expanding the body of scholarly knowledge and increasing readers' effectiveness as educators. The journal also focuses on facilitating the activities of both researcher-practitioners and practitioner-researchers, providing optimal opportunities for interdisciplinary and collaborative thought through blogging and other communications.

Walden University Publishing: http://www.publishing.waldenu.edu 